\title{
ANALYSIS OF INVESTMENT FACTORS WHICH ARE INFLUENCING THE GROWTH OF THE REPUBLIC OF SERBIA
}

\author{
Ivan Milojevic ${ }^{1}$ Svetlana Ignjatijević, ${ }^{2}$ Dragomir Đorđevićc ${ }^{3}$
}

\begin{abstract}
The subject of this research is empirical analysis of the factors which have influence on economic growth, whereas the main aim is to suggest adequate ways to overcome problems. We have analyzed the influence of budget deficit, personal consumption, inflation, real exchange rate, foreign trade balance and foreign direct investments (FDI) on economic growth. Furthermore, we measured the influence factors on the presence and movement of the budget deficit. Research paper uses the data obtained from the Statistical Office of the Republic of Serbia, World Bank and the IMF for the time period 2001-2011 and has been applied regression analysis method. Research results indicate that the real exchange rate, personal consumption and foreign trade balance are statistically significant for anticipating economic growth developments. Contrary to our expectations, the empirical analysis showed that FDI have a negative influence on the economic growth. The coefficient "public debt" is statistically significant and has a positive influence on the increase of budget deficit, whereas the increase of SDI and trade openness triggers a decrease in budget deficit. This research starts from the hypothesis that financing deficit limits economic growth and the inflow of FDI can't provide long-term economic growth. In the coming period Serbia needs to take advantage of the available resources and managing public finances, obeying laws and regulations and continuing with reforms are fundamental for achieving a stable business environment.
\end{abstract}

Key words: budget deficit, GDP, FDI, economic growth

JEL: E62, F34, H61.

1 Ivan Milojević, Ph.D., Full Professor, University of defense in Belgrade, Military Academy, Generala Pavla Jurisica Sturma Street No. 33, 11000 Belgrade, Serbia, E-mail: drimilojevic@gmail.com

2 Svetlana Ignjatijević, Ph.D., Assistant Professor, Faculty of Economics and Engineering Management in Novi Sad, Cvećarska Street no. 2, Novi Sad 21 000, Serbia,E-mail: ceca@, fimek.edu.rs svetlana.ignjatijevic@gmail.com

3 Dragomir Đorđević, Ph.D., Full Professor, Faculty of Economics and Engineering Management in Novi Sad, Cvećarska Street no. 2, Novi Sad 21 000, Serbia, E-mail:djordjevic@,fimek.edu.rs

EP 2016 (63) 4 (1205-1218) 


\section{Introduction}

Budget is the basic public document/act which regulates the process of financing all state functions (Đorđević, Ignjatijević, 2013). When the state functions have been precisely determined, the state starts the process of financial planning. In order to secure the process of financing public services, a country needs to have a special document which regulates the process of financing all of the state responsibilities (Jelčić, 1990). Most economists believe that a budget should provide balanced economic relations with its orientation. Gorčić (1990) emphasizes that the criterion for evaluating the policy of budget revenues and expenditures is actually their influence on employment, prices, economic development and payment balance.

With the development of modern macroeconomic theories, budget balance as a primary goal becomes replaced. What is advocated is the deficit budget financing as "the only way to increase economic growth, propel the development of a stagnating economy and alleviate the problem of unemployment" (Despotović et al., 2011). Budget deficit is a result of increased expenditures, decreased revenues, or increase of both expenditures and revenues with a much faster rate of increase in expenditures. Referential values up to $3 \%$ share of budget deficit and up to $60 \%$ share of public debt in gross domestic product have been chosen for the simple reason that it has been found that they truly enable the stability of prices in the long run, assuming the average economic growth of 3\% for GDP and inflation rate at 2\% per annum (Đorđević, Ignjatijević, 2013). The functioning of modern economy is very complex, with a lot of necessary information. The analysis of so-far fiscal policy shows that the measures and instruments of fiscal and monetary policy are only partially effective, in terms of securing a certain level of production, employment and consumption, while the results of action targeted at decreasing fiscal deficit are very poor. Financing deficit has until now proven to be insufficiently effective for increasing economic growth and modernization of economy. The rise in budget deficit in all economies was followed by a constant growth of public debt which is supposed to cover it (Komazec et al., 2009). In the period between the years 2000 and 2008, GDP was continuously growing, which, coupled with budget revenues, lead to a decrease in public debt. At the end of the first quarter 2011, public debt of the state equaled 12.7 billion euros which was an increase by 539.1 million euros compared to the end of 2010. In the structure of public debt, there was an increase in internal debt by 717.3 million and a decrease in the share of external debt by 178.2 million euros. Budget deficit in Serbia amounted to $6.7 \%$ at the end of the 2012 and so it has remained at this lowest level for the past ten years. In this research, we started from the hypothesis that a deficit financing limits economic growth and the inflow of FDI can not provide long-term economic growth. Therefore, the subject of this research is the analysis of the influence of factors on GDP. We have dynamically observed the causes of budget deficit and analyzed its influence as well as other factors' influences on the growth of GDP, wishing to suggest adequate measures to mitigate the problem. In the introduction, the subject of research is defined and the condition of the budget deficit and economic growth in Serbia is pointed out. In the literature review we presented 
the researchers whose conclusions are relevant for our study. The method of research is defined bellow. In the fourth section the results of research are presented, which will be discussed in the fifth chapter. Finally, in conclusion, measures for overcoming the limiting factors of economic growth are suggested.

\section{Literature review}

Saleh (2003) focused on theoretical debates and empirical studies of the influence of macro-economic variables on budget deficit. Empirical research results indicate a strong negative influence of public consumption whereas public investment consumption has a mild positive influence. Analyzing the relation between the budget deficit and current account deficit, this author confirms Keynes' attitude, according to which the process of stimulating state consumption increases import and so brings about the current account deficit. As stated, the main result of empirical research shows that the financing of budget deficit through monetarization leads to inflation.

David (2009) points to the influence of tax income on production and overall welfare. This author emphasizes that imposing taxes decreases investments, people save less and so banking systems have fewer resources at their disposal for granting loans. As a consequence, this negatively affects production and decreases new tax income.

Safdari et al. (2011) in their study point to the negative influence of population growth and budget deficit on private consumption. Authors conclude by saying that increased state consumption raises aggregate demand and so public consumption has a positive influence on private consumption. State governments with budget deficit finance their needs by increasing taxes or borrowings, due to which interest rates increase and the overall price levels.

Ahmad et al. (2000) confront traditional to modern approaches when it comes to the effects of state consumption. In traditional view, high state expenditures lead to increased public demand for goods and services, the consequences of which are increased interest rate and increase in the price of capital. In modern approach, state consumption is seen as a stimulus of investments. Research results indicate that openness is considered to be a favorable factor for the developing counties, while for the developed countries openness is not such an important factor for investments.

Saad et al. (2009) analyze the effects that budget deficit and other macro-variables can have on the demand for money. From their study it is evident that "co-integration test results indicated that a cointegrating vector is detected among real money demand, budget deficits, government expenditure, interest rate, consumer price index, and GDP. Hence, there is a long-run equilibrium relationship in the money demand function." Aisen et al. (2008) talked about the positive influence of budget deficit on interest rates.

Cebula et al. (2012) in their study analyze the influence of increased government expenditures on economic growth and the significance of budget deficit. The authors conclude that state governments should be careful when creating policies which 
generate budget deficit and a rise of long-term nominal interest rates. Research results suggest that such policies "along with the huge federal budget deficits and higher interest rates that are being forecasted for the U.S. in coming years, will decrease the rate of per capita real GDP growth in the U.S. Clearly, the latter will compromise U.S. living standards".

Tekin-Koru et al. (2003) analyze long-term relationship among budget deficit, inflation and monetary mass. A direct relationship between budget deficit and inflation is not legitimate in the case of Turkey. Empirical results do not support the theoretical approach that inflation is a result of active monetary policy which is targeted at maximizing seigniorage revenue. However, "this mode of deficit financing leading to the creation of near money with very high real interest costs and heavily restricted scope for an effective monetary policy may not be sustainable as the government securities-broad money ratio cannot grow without limit"(p. 595).

Sill (2005) tested whether there is a connection between budget deficit and inflation. This author emphasizes that monetary policy is used in order to harmonize budget deficit and that it is crucial for the influence of budget deficit on inflation. A logical question to be raised here is why in some countries budget deficit is connected with inflation while in others it is not. The author of this study, nevertheless, focused on inflation as a consequence of budget deficit. The author explains that "developing countries, however, often require revenue from seigniorage to meet their fiscal financing needs. Thus, these countries tend to show a strong link between fiscal deficits and subsequent inflation".

Daly et al. (2009) analyzed the influence of budget deficit and real exchange rates on the current account balance of payments. They emphasize that there are more ways for budget deficit to lead to a trade deficit. With "flexible exchange rates, an increase in government deficits would induce an upward pressure on real interest rates, causing capital inflows and thereby raising the foreign exchange value of domestic currency (i.e. an appreciation in real exchange rates)". Fiscal incentives increase the nominal income and worsen the current account balance. On the other hand, budget deficit increases domestic consumption and brings about the expansion of import.

Demir et al. (2008) analyzed the influence of public debt on macro-economic stability. By means of empirical research, authors found that there is a negative influence on interest rate, GNP and inflation rate. However, "among public domestic borrowing and GNP, it is available an opposite direction correlation".

Fatima et al. (2012) analyzed the influence of budget deficit on economic growth. They concluded that state governments should use all available resources in order to overcome the problems of budget deficit, alongside with controlling money supplies and limiting further borrowings. Baro (1979) also dealt with the influence of budget deficit on economic growth and this author's research results indicate that there is a positive correlation. As opposed to these studies, Huynh (2007) showed on the example of Vietnam that there is a negative influence of budget deficit on economic growth. The 
relationship between budget deficit and investments was also analyzed by Bahmani (1999), Ghali et al. (1997), who showed that there is a strong influence of budget deficit, which according to these authors contributes to an increase in economic growth.

\section{Methods}

Regression analysis was used in the study in order to analyze the empirical relationship among personal consumption, inflation, real exchange rate, foreign trade balance, FDI, budget deficit and economic growth. At the same time, is observed the influence of economic growth, public debt, FDI, inflation, openness of economy and personal consumption on the movements of budget deficit. One of the main variables is GDP per capita, which is at the same time an indicator of market size (Cannonier et al., 2007) or market development (Kolstad et al., 2004). As a measure of the price of unchangeable goods and importing prices we will use the exchange rate. Inflation rate is a significant macro-economic indicator, export and import are important indicators of foreign trade balance, and value of public consumption is an indicator of the role of government, whereas the sum of export and import (total foreign trade turnover in GDP) is a good indicator of economic openness. It is logical to expect that increased FDI influx will cause a decrease in public revenues from privatization (Flexner, 2000).

In our study we used data obtained from the Statistical Office of the Republic of Serbia, World Bank, and IMF for the period between 2001 and 2011. Following the examples of Cannonier et al. (2007) and Fatima et al. (2012) we used natural logarithm values and econometric software package STATA. The assumption was that there is linear dependence between the analyzed factors and GDP, and that the mentioned factors affect budget deficit.

In theoretical considerations, the following models are used:

$$
\begin{aligned}
& L n(G D P)=\beta_{0}+\beta_{1} \ln (F D I)+\beta_{2} \ln (E X C H)+\beta_{3} \ln (I N F L)+\beta_{4} \ln (B D)+\beta_{5} \ln (F T B)+{ }_{6} \ln (P C)+u \\
& \ln (B D)=\beta_{0}+\beta_{1} \ln (G D P)+\beta_{2} \ln (D E B T)+\beta_{3} \ln (F D I)+\beta_{4} \ln (I N F)+\beta_{5} \ln (I M P E X P)+{ }_{6} \ln (P C)+u
\end{aligned}
$$

Where the meanings of symbols are:

GDP $=$ Gross Domestic Product (GDP)

$\mathrm{EXCH}=$ Real Exchange Rate

$\mathrm{INFL}=$ Inflation

$\mathrm{PC}=$ Personal consumption

$\mathrm{DEBT}=$ External Debt

IMPEXP $=$ Imports plus Exports of goods and services 
$\mathrm{FTB}=$ Foreign trade balance

$\mathrm{FDI}=$ Foreign direct investments

$\mathrm{BD}=$ Budget Deficit

$\mathrm{u}=$ Stochastic Error Terms

Where, $\beta 0, \beta 1, \beta 2, \beta 3, \beta 4, \beta 5, \beta 6$ are the respective parameters.

\section{Data and empirical analysis}

In the period after 2000 a high degree of trade liberalization and capital balance, macroeconomic stability and privatization of the financial sector were achieved. In the analyzed period, public finances of the Republic of Serbia were consolidated, from the revenue and expenditure side of the budget (Galjak, Bošković, 2015). The consolidation of internal and external debt affected the decrease of fiscal deficit from a 10\% GDP in the year 2000, to a $4.2 \%$ GDP in the year 2009, with a rising trend in $2012(6.7 \%$ GDP). High fiscal deficit during the ten-year period is a result of a low level of collected taxes and perhaps great demand for state action and public goods. Additional pressure to increase state consumption was the result of transition, or, more precisely, increase in unemployment. A high level of deficit reflected on the amount of public debt. The state compensated for the lack of revenues by privatization and selling the state property, whereas the necessary amount of money was obtained by taking a loan. Besides taking loans from banks and other financial institutions, the state started issuing securities and assuming responsibility in the form of warranties (Krstić, 2016).

Table 1. Main indicators of macro-economic developments in Serbia (2001-2011)

\begin{tabular}{|l|r|r|r|}
\hline Indicators & 2001 & 2005 & 2011 \\
\hline Total GDP (\%) & 5.6 & 5.6 & 1.6 \\
\hline GDP per capita $(€)$ & 1.709 & 2.729 & 4.290 \\
\hline Foreign trade deficit (mil. Euro) & -2.837 & -4.831 & $-5.808,6$ \\
\hline Foreign direct investments (mil. Euro) & 184 & 1.244 .6 & 1.827 \\
\hline Current account deficit (\% of GDP) & -7.6 & -10.2 & -9.6 \\
\hline Unemployment rate (\%) & 12.23 & 20.8 & 23.7 \\
\hline Inflation rate (\%) & 91.8 & 16.5 & 11.1 \\
\hline
\end{tabular}

Source: Statistical Office of the Republic of Serbia and Ministry of Finance, Public Finance Bulletin for 2009 and 2012

Although trade liberalization and integration into international product and financial flows affected capital influx, in the recent past Serbia was faced with a lack of domestic and foreign capital. Domestic savings are insufficient for maintaining a constant economic growth and servicing foreign/external debt. Foreign direct investments have somewhat increased in the last few years compared to borrowings from abroad, and due 
to an increase in final consumption, foreign trade turnover also increased i.e. import of goods and services. The influence of trade openness on economic development has been achieved through FDI and increased work productivity. Current account deficit has been financed by foreign capital, in the form of loans and FDI (Vukša et al., 2015).

We have already pointed out that the influence of factors varies from one country to another. Wishing to observe and analyze the influence of factors on the economic growth of Serbia, we analyzed the influences of income, public debt, primary money, real exchange rate, inflation, personal consumption, foreign trade deficit, FDI and budget deficit. In the continuation of this study we provide the results of regression analysis - Table 2.

Table 2. Regression analysis of influence factors on economic growth

\begin{tabular}{|l|l|l|l|l|l|l|l|}
\hline Multiple R & 0.998901 & & $d f$ & $S S$ & $M S$ & $F$ & $\begin{array}{l}\text { Significance } \\
F\end{array}$ \\
\hline R Square & 0.997804 & Regression & 6 & 0.179112 & 0.029852 & 302.918 & $2.88 \mathrm{E}-05$ \\
\hline Adjusted R & 0.99451 & Residual & 4 & 0.000394 & $9.85 \mathrm{E}-05$ & & \\
\hline Standard Error & 0.009927 & Total & 10 & 0.179506 & & & \\
\hline Observations & 11 & & & & & & \\
\hline
\end{tabular}

Source: Authors' calculation

Based on the coefficient of determination (R-Sq), we can conclude that $99.78 \%$ of chnages in GDP can be accounted for by variations of all factors. The constant 1.039593 shows a hypothetical value of GDP when all factors equal zero. By empirical analysis we tried to determine the probability of the existence of correlation. The empirical level of $F$ distribution is 302.918 and is higher than the critical value (Significance $F-2,88 E$ 05) of the $F$ distribution. The resulting value indicates that a high value of $F$ distribution is not coincidental, and that the regression equation is applicable in cases when we wish to anticipate movements of GDP. T statistics should determine the usefulness of every coefficient in anticipating the movements of GDP. All coefficients were tested and we got absolute values of t-statistics as results. By comparing all absolute values and $\mathrm{t}-$ critical, we can conclude that for the anticipation of movements, the crucial factors are: real exchange rate, foreign trade, personal consumption and coefficient of direction.

Table 3. Regression statistics - influence of various factors

\begin{tabular}{|l|l|l|l|l|l|l|l|l|}
\hline & Coefficients & $\begin{array}{l}\text { Standard } \\
\text { Error }\end{array}$ & t Stat & P-value & $\begin{array}{l}\text { Lower } \\
95 \%\end{array}$ & $\begin{array}{l}\text { Upper } \\
95 \%\end{array}$ & $\begin{array}{l}\text { Lower } \\
95.0 \%\end{array}$ & $\begin{array}{l}\text { Upper } \\
95.0 \%\end{array}$ \\
\hline Intercept & 1.03959 & 0.20318 & 5.11659 & 0.00690 & 0.47547 & 1.60371 & 0.47547 & 1.60371 \\
\hline $\mathrm{X}$ 1 FDI & -0.00623 & 0.02330 & -0.26734 & 0.80242 & -0.07091 & 0.05845 & -0.07091 & 0.05845 \\
\hline $\begin{array}{l}\text { X 2 Real } \\
\text { exchange rate }\end{array}$ & 0.27364 & 0.04013 & 6.81955 & 0.00242 & 0.16223 & 0.38504 & 0.16223 & 0.38504 \\
\hline X 3 Inflation & -0.17886 & 0.08142 & -2.19677 & 0.09299 & -0.40492 & 0.04720 & -0.40492 & 0.04720 \\
\hline $\begin{array}{l}\text { X 4 Budget } \\
\text { deficit }\end{array}$ & -0.00560 & 0.02857 & -0.19611 & 0.85409 & -0.07371 & 0.08492 & -0.07371 & 0.08492 \\
\hline
\end{tabular}




\begin{tabular}{|l|l|l|l|l|l|l|l|l|}
\hline $\begin{array}{l}\mathrm{X} \text { 5 Foreign } \\
\text { trade balance }\end{array}$ & 0.31716 & 0.05882 & 5.39163 & 0.00572 & 0.15384 & 0.48048 & 0.15384 & 0.48048 \\
\hline $\begin{array}{l}\mathrm{X} \text { 6 Personal } \\
\text { consumption }\end{array}$ & 0.75221 & 0.16182 & 4.64849 & 0.00967 & 0.30293 & 1.20148 & 0.30293 & 1.20148 \\
\hline
\end{tabular}

Source: Authors' calculation

Results show a negative influence of inflation on economic growth $\left(\beta_{3}=-0.17886\right.$; $\mathrm{p}=0.092987) .1 \%$ of increase in inflation will lead to a 0.17886 times smaller GDP. Budget deficit has a slight negative influence on economic growth $\left(\beta_{4}=-0.005602 ; \mathrm{p}=\right.$ $0.196107) .1 \%$ of increase in earnings will lead to a 0.005602 times smaller GDP. In our research, personal consumption has a positive effect on GDP $\left(\beta_{6}=0.752205 ; \mathrm{p}=\right.$ 0.009672). An increase of 1\% triggers a 0.752205 times increased GDP. Results show a negative influence of FDI on economic growth $\left(\beta_{1}=-0.00623 ; \mathrm{p}=0.802423\right)$.

We have simultaneously observed and analyzed the influence of factors on the budget deficit. We have found that $91,75 \%$ of changes in budget deficit can be accounted for by changes in all factors. The empirical level of $\mathrm{F}$ distribution is 7.417031, which is higher than the critical value (Significance F - 0,03646).

Table 4. Regression analysis of influence factors on the budget deficit

\begin{tabular}{|l|l|l|l|l|l|l|l|}
\hline Multiple R & 0.957878 & & $d f$ & \multicolumn{1}{l}{ SS } & MS & F & \multicolumn{2}{|l|}{\begin{tabular}{l} 
Fignificance \\
\hline R Square
\end{tabular}} & 0.917529 & Regression & 6 & 1.025925 & 0.170987 & 7.417031 & 0.03646 \\
\hline Adjusted R & 0.793824 & Residual & 4 & 0.092213 & 0.023053 & & \\
\hline Standard Error & 0.151833 & Total & 10 & 1.118138 & & & \\
\hline Observations & 11 & & & & & & \\
\hline
\end{tabular}

Source: Authors'calculation

The result of $F$ distribution shows that this value is not coincidental but rather significant for the anticipation of budget deficit movement. $T$ - statistics shows that the value of public debt is the most significant for the anticipation of budget deficit movement.

Table 5. Regression statistics - influence of various factors

\begin{tabular}{|c|c|c|c|c|c|c|c|c|}
\hline & Coefficient & Standard Error & $\mathrm{t}$ Stat & P-value & $\begin{array}{c}\text { Lower } \\
95 \%\end{array}$ & $\begin{array}{c}\text { Upper } \\
95 \%\end{array}$ & $\begin{array}{c}\text { Lower } \\
95.0 \%\end{array}$ & $\begin{array}{c}\text { Upper } \\
95.0 \%\end{array}$ \\
\hline Intercept & -19.443 & 5.364409 & -3.62444 & 0.022269 & -34.337 & -4.549 & -34.337 & -4.549 \\
\hline X 1 GDP & 1.14372 & 2.170669 & 0.526897 & 0.626132 & -4.88302 & 7.170465 & -4.88302 & 7.170465 \\
\hline $\begin{array}{c}\text { X 2 Public } \\
\text { debt }\end{array}$ & 2.339933 & 0.799029 & 2.928472 & 0.042879 & 0.121474 & 4.558392 & 0.121474 & 4.558392 \\
\hline
\end{tabular}




\begin{tabular}{|c|c|c|c|c|c|c|c|c|}
\hline X 3 FDI & -0.39318 & 0.274093 & -1.43448 & 0.22475 & -1.15418 & 0.367824 & -1.15418 & 0.367824 \\
\hline X 4 Inflation & -1.44107 & 1.286637 & -1.12003 & 0.325407 & -5.01335 & 2.131206 & -5.01335 & 2.131206 \\
\hline $\begin{array}{c}\text { X 5 Openness } \\
\text { export+ } \\
\text { import }\end{array}$ & -1.0794 & 1.379818 & -0.78228 & 0.477767 & -4.91039 & 2.751585 & -4.91039 & 2.751585 \\
\hline $\begin{array}{c}\text { X 6 Personal } \\
\text { consumption }\end{array}$ & 3.393451 & 2.557117 & 1.327061 & 0.255171 & -3.70624 & 10.49314 & -3.70624 & 10.49314 \\
\hline
\end{tabular}

Source: Authors' calculation

GDP has a positive influence in the budget deficit. 1\% of the increase in GDP will lead to an increase in budget deficit by 1.14372 times. Personal consumption is an important factor of economic tendencies. An increase in personal consumption will trigger an increase in budget deficit by 3.393 times. An increase in FDI and trade openness will lead to a decrease in budget deficit. It is important to emphasize that an increase in public debt has a very strong influence on the movement of budget deficit. Its increase will trigger an increase in budget deficit by 2.3399 times. A significant factor of public debt sustainability of Serbia is a structural change and a decrease in the scope of public consumption. It is necessary to decrease the share of consolidated public expenditures in order to decrease the share of fiscal deficit in GDP. It is possible to stabilize the budget deficit by new borrowings under more favorable conditions or by printing money.

\section{Results and discussion}

As we see in the literature review a number of authors have researched this relation. Our intention was not to revise the mentioned model, but primarily to observe all aspects which are relevant for our economy.

Tekin-Koru, Özmen (2003) have shown the negative impact of inflation on economic growth, which was in line with our results. Our results are in correlation with the conclusion by Fatima et al. (2012) about the negative impact of the budget deficit. A negative influence of budget deficit on the growth of GDP is primarily a consequence of transition and increase in unemployment. A long period of decreased economic activities and smaller budget revenues has had an unfavorable effect on the amount of budget deficit. Research results of the influence of factors on budget deficit indicate a high interdependence between the increase of GDP and budget deficit. On one hand, an increase in public consumption leads to an increase in aggregate demand and GDP; while, on the other hand, precisely the increase in GDP triggers an increase in budget deficit. Insufficient resources and lack of finances in the budget have partly been compensated for by privatization, and partly by new borrowings. An increase in budget expenditures contributes to an increase in aggregate demand (Sefdari et al., 2011). However, an increase in budget deficit stresses the need to collect more financial 
resources through taxing or borrowings (Raičević et al., 2016). That is how we end up with a decrease in available income, decrease in private consumption and lastly- a decrease in GDP. Empirical results are in accordance with the findings of Saleh (2005) who states that an increase in budget consumption triggers an increase in import, current account deficit and, finally, a decrease in GDP. The obtained results have been harmonized with the empirical results of Daly et al. (2009), who said that an increase in public consumption leads to the expansion of import and current account deficit.

Personal consumption is an important factor of economic developments. A decrease in demand for consumption goods will trigger a decrease in demand for investment goods (Ignjatijević, 2011). A decrease in investments brings a decrease in production, rise of unemployment and, as Keynes claims- a fall in demand triggers great depression (Rosić, 2003). Contrary to numerous studies which point to a positive influence of FDI on economic growth, our research leads us to a different conclusion. There is an evident negative influence of FDI on economic growth. Reasons for this are numerous: investment environment, business environment and incomplete reform processes. There is an interesting correlation of investment incentives on behalf of the state, aimed at attracting new FDI and economic growth. Although this study does not provide an analysis of the direct influence of fiscal stimuli, there is an obvious negative influence on economic growth. For investment incentives with truly positive results, or in other words, for truly justified state expenditures and FDI which bring positive results in terms of economic growth, it is necessary for Serbia to undertake a number of measures. Firstly, it is important to analyze in detail the effects of investment incentives and observe the simultaneous use of incentives towards domestic and foreign businesses. FDI will have a positive effect on economic growth, provided that the state encourages investing in human resources and their potentials, especially in management development. Another condition is for local firms and businesses to be capable and motivated to utilize the latest technology. The reason for this should be sought in insufficient scope of FDI, due to instability, high sensitivity of economy to climatic, agricultural and trading risks, which is exactly what Lensink et al. (2001) indicate. Another reason is the size of the market and insufficient investments in human capital. Globerman et al. (2002) arrive at a similar conclusion when they say that different effects of FDI are possible, depending on political reforms as well. When Lensink et al. (2001) observe the influence of SDI on economic growth and analyze factors which can have a positive influence in terms of attracting new FDI, they also state that economies with high risk levels are not appealing to investors. The mentioned results are in accordance with our conclusion that reforms are necessary, as well as political stability, continuity of economic reforms and as Tian et al. (2004) claim- a faster pace of technological development is necessary, too. So, we have doubts when it comes to the hypothesis that FDI necessarily contribute to the economic development of less developed countries. We agree that the openness of a country towards FDI can have a positive effect on economic growth, alongside with industrial infrastructure, human capital and geographical position. This is fully in accordance with the conclusions made by Anderson et al. (2004). However, there is also a negative influence of a large and ineffective public sector which limits the positive effects of FDI. 


\section{Conclusion}

Research results indicate that the presented models are highly relevant for anticipating the developments of economic growth and budget deficit. We have found that there is a negative influence of inflation on economic growth. The state tried to decrease public debt and stabilize budget deficit, which triggered inflation through the process of monetization. We have also found that budget deficit has a negative influence on economic growth, which is in accordance with the hypothesis. The reasons for this should primarily be sought in insufficient resources. With the aim to stabilize the macroeconomic situation and public debt, the state increased public expenditures, which, coupled with limited revenues, resulted in the increase of budget deficit. Trying to overcome that situation, the state created development projects, using financial resources gained from privatization and a part of FDIs to cover the budget deficit. No favorable trade structure and institutional deregulation of a state in transition seemed as a favorable situation for this possibility- alternative. Since the resources were not used in the real economic area, they did not contribute to the production increase and thus the increase in budget revenues. On the other hand, a bigger financial burden, with the purpose to decrease the budget deficit, triggered the decrease in available income, personal consumption and eventually the fall of GDP. We have proved the assumption that an increase in budget deficit enhances the foreign trade deficit and influences the expansion of import. Personal consumption has a positive influence on the movement of GDP. Contrary to our expectations, FDI have a negative influence on economic growth. In the course of our research, we found that the public debt and personal consumption are significant factors for the movements of budget deficit. We can conclude that the budget deficit was further increased due to obligations related to the servicing of public debt. The state can thus choose between entering into a new debt agreement under more favorable conditions and printing money. If in the following period interest rate becomes higher than the growth rate of GDP, this will lead to a further increase in the value of budget deficit and public debt. In the coming period, Serbia has to take advantage of the available resources. From the perspective of overcoming the foreign trade deficit, FDI should be directed towards export-oriented production and primarily use the comparative advantages of food and textile industries of Serbia. Obeying international agreements and stronger integration should bring positive effects in the economic growth. Primarily, Serbia needs to control the public debt in order to decrease the scope and structural changes of public consumption and also to decrease the share of budget deficit in GDP. The control of budget deficit will have a positive effect on economic growth. Hence, with a change of the existing structure of public consumption, rather than further indebtedness, it is necessary to decrease the budget deficit. The government can initiate an increase in direct and indirect taxes, but cautiously, so as not to bring about the decrease in personal consumption and thus investment consumption and slowdown of economic growth. Logically, what remains is the expenditure side of the budget. The continuation of reforms in the public sector and bringing of new law on public enterprises and public purchases and acquisitions/tenders are of primary importance. New law related to public enterprises and public acquisitions and competitions should be the priority. In the coming period, particular attention should 
be paid to the improvement of investment conditions and environment, with the purpose of technical and technological modernization and improvement of economic competitiveness. It is important to improve the business environment and by doing so encourage businesses to innovate and increase productivity, thus increasing employment and process of collecting public income.

\section{Literature}

1. Ahmad, H., Millar, S. M. (2000): Crowding-out and crowding-in effects of the components of government expenditure, Contemporary Economic Policy, vol. 18, no. 1, pp. 124-133.

2. Aisen, A., Hauner, D. (2008): Budget Deficits and Interest Rates: A Fresh Perspective, IMF Working Papers, vol. 42, pp. 1-19.

3. Anderson, G., Ge, Y. (2004): Do Economic Reforms Accelerate Urban Growth? The Case of China, Urban Studies, vol. 41, no. 11, pp. 2197-2210.

4. Bahmani, O.M. (1999): Do federal budget deficits crowd out or crowd in private investment?, Journal of Policy Modeling, vol. 21, no. 5, pp. 633-640.

5. Barro, R.J. (1979): On the Determination of the Public Debt, Journal of Political Economy, vol. 87, pp. 940-971.

6. Cannonier, C., Francis, B., Lorde, T. (2007): Foreign Direct Investment and Trade in the Eastern Caribbean Currency Union, Journal Of Eastern Caribbean Studies, vol. 32, no. 3, pp. 23-49.

7. Cebula, R., Mixon, F. (2012): The Impact of Fiscal and Other Economic Freedoms on Economic Growth: An Empirical Analysis, International Advances in Economic Research, vol. 18, no. 2, pp. 139-149.

8. Daly, V., Siddiki, J.U. (2009): The twin deficits in OECD countries: co-integration analysis with regime shifts, Applied Economics Letters, vol. 16, no. 11, pp. 1155 1164.

9. David, N. (2009): Efficiency aspects of increasing inheritance taxes while decreasing income taxes, Applied Economics, vol. 41, no. 26, pp. 3359-3366.

10. Demir, M., Sever, E. (2008): Kamu iç borçlanmasinin büyüme, faiz ve enflasyon orani üzerindeki etkileri, Electronic Journal of Social Sciences, vol. 7, no. 25, pp. 170-196.

11. Despotović, D., Veličković, D., Ristić, J. (2011): Budžetski deficit i privredni rast - teorijske kontroverze, Ekonomika, vol. 57, no. 2), pp. 146-157.

12. Đorđević, D., Ignjatijević, S. (2013): Javne finansije, Novi Sad: Fakultet za ekonomiju i inženjerski menadžment.

13. Fatima, G., Ahmed, M., Ur Rehman, W. (2012): Consequential Effects of Budget Deficit on Economic Growth of Pakistan, International Journal of Business \& Social Science, vol. 3, no. 7, pp. 203-208.

14. Flexner, N. (2000): Foreign direct investment and economic growth in Bolivia, 
1990-1998. Economic Policy Division, Central Bank of Bolivia, La Paz-Bolivia. http://econwpa.wustl. edu/eps/mac/papers/0309/0309009.pdf.

15. Galjak, I., Bošković, Č. (2015): Istorijski aspekti razvoja tržišta kapitala $i$ korporativnog upravljanja, Oditor, Beograd, no. 10, pp. 10-16.

16. Ghali, K.H., Al-Shamsi, F. (1997): Fiscal policy and economic growth: a study relating to the United Arab Emirates, Economia Internazionale / International Economics, vol. 50, no. 4, pp. 519-533.

17. Globerman, S., Shapiro, D. (2002): Governance infrastructure and US foreign direct investment, Journal of International Business Studies, vol. 34, no. 1, pp. 19-39.

18. Gorčić, J. (1994): Finansije i finansijsko pravo, Beograd: Radnička štampa.

19. Huynh, N.D. (2007): Budget Deficit and Economic Growth in Developing Countries: The case of Vietnam, Kansai Institute for Social and Economiic Research (KISER).

20. Ignjatijević, S. (2011): Effect of gross domestic product and income of personal consumption, Ekonomija: teorija i praksa, vol. 4, no. 1, pp. 105-110.

21. Jelčić, B. (1990): Nauka o finansijama I finansijsko pravo, Zagreb: Narodne novine.

22. Krstić, S. (2016): Značaj institucije centralne banke za nacionalnu ekonomiju, Oditor, Belgrade, Serbia, vol. 2, no. 2, pp. 18-26.

23. Kolstad, I., Villanger, E. (2004): Determinants of Foreign Direct Investments in Services, CMI Working Paper, WP 2.

24. Komazec, S., Ristić, Ž. (2009) Makroekonomija, Beograd: Etnostil.

25. Lensink, R., Morrissey, O. (2001): Foreign direct investment: flows, volatility and growth in developing countries, University of Groningen.

26. Safdari, M., Mehrizi, M., Elahi, M. (2011): The Effect of Budget Deficit on Private Consumption in Iran, American Journal of Scientific Research, vol. 39, pp. 40-46.

27. Raičević, B., Ignjatijević, S., Milojević, I. (2016): Finansijska analiza uticaja stranih direktnih investicija na ekonomski rast zemalja u razvoju, Ekonomika poljoprivrede, vol. 63, no. 2, pp. 649-663.

28. Rosić, I. (2003): Nacionalna makroekonomija, Kragujevac: Ekonomski fakultet.

29. Saad, W., Kalakech, K. (2009): The Impact of Budget Deficits on Money Demand: Evidence from Lebanon, Middle Eastern Finance and Economics, vol. 3, pp. 6576.

30. Saleh, A.S. (2003): The Budget Deficit and Economic Performance: A Survey, Working Paper Series, WP03-12, School of Economics and Information System, University of Wollongong, Australia.

31. Sill, K. (2005): Do budget deficits cause inflation?. Business Review, Q3, pp. 26-33.

32. Tekin-Koru, A., Özmen, E. (2003): Budget deficits, money growth and inflation: 
the Turkish evidence, Applied Economics, vol. 35, no. 5, p. 591.

33. Tian, X., Lin, S., Lo, V.I. (2004): Foreign Direct Investment and economic performance in transition economies: Evidence from China, Post-Communist Economies, vol. 16, no. 4, pp. 497-510.

34. Vukša, S., Anđelić, D., Kolarski, I. (2015): Uloga ekonomske politike u ekonomskim krizama, Oditor, Beograd, no. 12, pp. 4-12.

\title{
INVESTICIONA ANALIZA FAKTORA EKONOMSKOG RASTA REPUBLIKE SRBIJE
}

\section{Ivan Milojević ${ }^{4}$ Svetlana Ignjatijević, ${ }^{5}$ Dragomir Đorđević ${ }^{6}$}

\begin{abstract}
Apstrakt
Predmet ovog istraživanja je empirijska analiza faktora koji utiču na ekonomski rast, dok je glavni cilj predlaganje adekvatnih načina za prevazilaženje problema. U radu smo analizirali uticaj budžetskog deficita, lične potrošnje, inflacije, realnog kursa, spoljno-trgovinskog bilansa i stranih direktnih investicija (SDI) na ekonomski rast. Osim toga, merili smo koji faktori utiču na prisustvo i kretanje budžetskog deficita. U našem istraživanju korišćeni su podaci dobijeni od Zavoda za statistiku Republike Srbije, Svetske banke i MMF-a za period 2001-2011 i primenjena je regresija kao metod analize. Rezultati istraživanja pokazuju da je realni devizni kurs, lična potrošnja $i$ spoljnotrgovinski bilans statistički značajan za predviđanje razvoja i ekonomskog rasta. Suprotno našim očekivanjima, empirijska analiza je pokazala da SDI imaju negativan uticaj na ekonomski rast. Koeficijent "javni dug” je statistički značajna i ima pozitivan uticaj na povećanje budžetskog deficita, dok je povećanje SDI i trgovinske otvorenosti izaziva smanjenje budžetskog deficita. U ovom istraživanju, počeli smo od hipoteze da finansiranje deficita ograničava ekonomski rast i priliv SDI i ne može da obezbedi dugoročni ekonomski rast. U narednom periodu Srbija mora da iskoristi raspoložive resursa $i$ upravljanja javnim finansijama, omogući poštovanje zakona i nastaviti sa reformama su od fundamentalnog značaja za postizanje stabilnog poslovnog okruženja.
\end{abstract}

Ključne reči: budžetski deficit, BDP, SDI, ekonomski rast

4 Redovni professor, dr Ivan Milojević, Univerzitet odbrane u Beogradu, Vojna Akademija, Ulica Generala Pavla Jurisica Sturma br. 33, 11000 Beograd, Srbija, Telefon: +381 60070 26 97, E-mail: drimilojevic@gmail.com

5 Docent, dr Svetlana Ignjatijević, Fakultet za ekonomiju i inženjerski menadžment u Novom Sadu, Cvećarska ulica br. 2, Novi Sad 21 000, Srbija, E-mail: ceca@fimek.edu.rs svetlana. ignjatijevic@gmail.com

6 Redovni professor, dr Dragomir Đorđević, Fakultet za ekonomiju i inženjerski menadžment u Novom Sadu, Cvećarska ulica br. 2, Novi Sad 21 000, Srbija, E-mail:djordjevic@,fimek.edu.rs 